\title{
Impulse control disorders in Parkinson's disease: seeking a roadmap toward a better understanding
}

\author{
Roberto Cilia · Thilo van Eimeren
}

Received: 4 January 2011/Accepted: 23 March 2011 / Published online: 4 May 2011

(C) The Author(s) 2011. This article is published with open access at Springerlink.com

\begin{abstract}
The development of an impulse control disorder (ICD) is now recognized as a potential nonmotor adverse effect of dopamine replacement therapy in Parkinson's disease (PD). Here, recent epidemiological, neurophysiological and genetic advances are summarized to outline potential mechanisms involved. It is safe to say that dopaminergic drugs, particularly dopamine agonists, are able to induce ICDs only in a minority of patients, while the majority are somehow protected from this adverse effect. While it seems clear that men with earlyonset PD are more vulnerable, other predisposing factors, such as various current or pre-PD personality traits, are a matter of debate. In terms of neurophysiological advances, one may find striking analogies to the addiction literature suggesting a causal chain beginning with certain predisposing conditions of striatal dopamine synapses, an "unnatural" increase of dopamine stimulation and a characteristic pattern of resulting functional changes in remote networks of appetitive drive and impulse control. Future prospects include potential add-on medications and the possible identification of genetic predispositions at a genome-wide scale. Functional imaging of pharmacogenetic
\end{abstract}

R. Cilia

Parkinson Institute, Istituti Clinici di Perfezionamento, via Bignami 1, 20126 Milan, Italy

e-mail: roberto.cilia@gmail.com

T. van Eimeren

NeuroImage Nord, Hamburg-Kiel-Luebeck, Kiel, Germany

T. van Eimeren $(\square)$

Neurozentrum, Campus Kiel, Universitätsklinik SchleswigHolstein, Arnold-Heller-Str. 3, Haus 41, 24105 Kiel, Germany

e-mail: tvaneimeren@gmail.com interactions (imaging pharmacogenomics) may be an important tool on that road.

Keywords Imaging - Gambling - Addiction - Impulsive · Compulsive $\cdot$ Dopamine agonist

\section{Introduction}

Impulse control disorders (ICDs), such as pathological gambling, compulsive shopping, binge eating and hypersexuality may develop as nonmotor adverse effects of dopamine replacement therapy in patients with Parkinson's disease (PD) (Driver-Dunckley et al. 2003; Seedat et al. 2000). In this review, we aim to summarize promising recent advances in characterizing (1) circumstances under which these behavioral disturbances appear, (2) neurobiological trigger mechanisms that may be involved and (3) possible neurophysiologic and genetic makeups that may help explain why some individuals are more vulnerable than others. For the sake of focus, certain types of impulsive and repetitive behavior that are observed in PD will not be discussed in this review. While there is growing evidence that electric stimulation of the subthalamic nucleus blocks the so-called 'hyperdirect' pathway of the basal ganglia, which may in turn produce a certain type of impulsivity (Frank et al. 2007), the exact relationship between subthalamic stimulation in PD and ICDs is unclear, as these abnormal behaviors may either follow neurostimulation (Lim et al. 2009; Volkmann et al. 2010) or resolve after dopaminergic dose reduction associated with successful surgery (Ardouin et al. 2006; Bandini et al. 2007; Witjas et al. 2005). It is therefore conceivable that subthalamic stimulation and dopaminergic medication may both lead to impulsivity, yet by different neurobiological 
mechanisms (Dalley et al. 2011). Although compulsive anti-Parkinsonian drug use-commonly referred to as dopamine dysregulation syndrome (DDS) - is sometimes associated with the development of ICDs in PD, epidemiological findings regarding DDS are markedly different from ICDs insofar as DDS usually develops as a complication of long-term dopaminergic therapy in advanced PD (O'Sullivan et al. 2009). Sometimes associated with DDS are repetitive, complex stereotyped behaviors (e.g., collectionism), described as punding (Evans et al. 2004). Even though punding certainly has elements of compulsions, it is felt to lie outside of the ICD spectrum (Evans et al. 2009).

\section{Clinical observations}

\section{Epidemiology of ICDs in PD}

A recent blinded, multi-center cross-sectional study with over 3,000 patients in North America constitutes the strongest effort yet to gather scientific evidence about the circumstances, in which ICDs in PD may occur (Weintraub et al. 2010). Similar to epidemiological studies in other PD populations (Lee et al. 2010), one or more forms of ICD was found in $13.6 \%$ of medicated PD patients. Moreover, the risk to develop an ICD appeared to increase threefold when dopamine agonists (DAAs) were part of the therapeutic regimes. This finding was independent of the type of DAA used, but combinational use with levodopa was found to be a contributing factor. Interestingly, ICDs have also been identified with similar or even higher frequencies in other DAA-treated conditions such as restless-legs syndrome, prolactinoma or fibromyalgia (Cornelius et al. 2010; Grosset et al. 2007; Holman 2009). Although this certainly is a strong indication for a specific pharmacological trigger mechanism of DAAs, it has to be noted that the prevalence of ICDs in PD patients on dopaminergic medication excluding DAAs was still found to be much higher than in the general population (Crockford et al. 2008). One of the most interesting findings of this crosssectional study was the absence of a significant dose relationship for DAAs, despite the fact that in the individual patient with a DAA-induced ICD, a dose threshold does sometimes feel quite palpable (Weintraub et al. 2010). Of note, a different epidemiological study showed that such a dose relationship may indeed be found, when clinical parameters including risk factors (see below) are taken into account (Lee et al. 2010). This indicates that the development of ICDs may stem from an interaction of a specific pharmacological trigger with intrinsic neurobiological vulnerability factors.

Apart from unusual manifestations of ICDs (Bienfait et al. 2010; Bonfanti and Gatto 2010; Odiyoor et al. 2009;

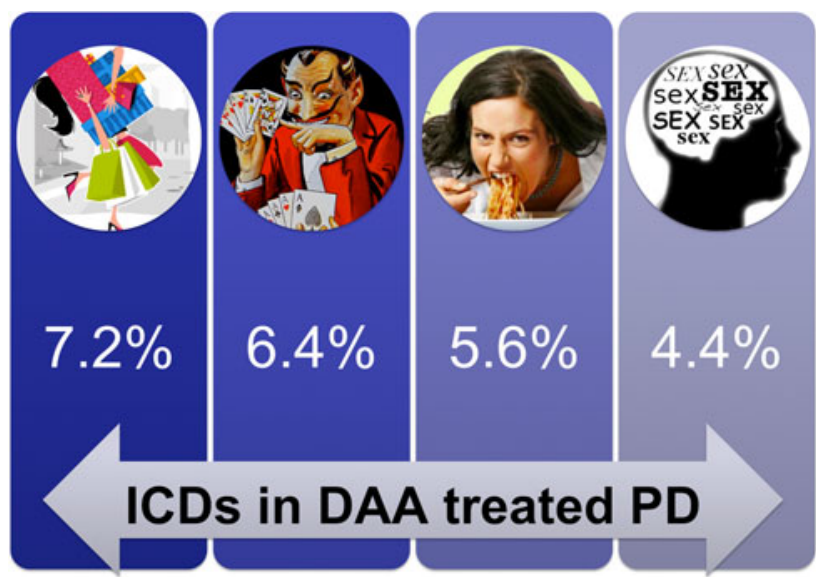

Fig. 1 Prevalence of the most frequent impulse control disorders (ICDs) in PD patients on dopamine agonists (DAA) according to the DOMINION study (Weintraub et al. 2010). From left to right: compulsive shopping, pathological gambling, binge eating and hypersexuality

Pinggera et al. 2009), pathological gambling, compulsive shopping, binge eating and hypersexuality seem to be equally common in DAA-medicated PD (Fig. 1). However, men seem to be more prone to develop pathological gambling or hypersexuality, while women have higher rates of compulsive shopping and binge eating. It is yet unclear how much of these differences may stem from differences in the mesocorticolimbic reward system (Hoeft et al. 2008; Munro et al. 2006) or reporting biases due to social acceptance.

\section{Factors of individual predisposition}

Male gender, early-onset PD, current or pre-PD personality traits characterized by high impulsivity and novelty-seeking personality traits, family or personal history of ICD symptoms or substance abuse (including current smoking) may all be regarded as considerable risk factors (Weintraub et al. 2010). The mechanisms of male preponderance are unclear, but imaging studies comparing men with women after exposure to rewarding stimuli have shown higher release of dopamine in the ventral striatum (Munro et al. 2006) and increased activation of the mesocorticolimbic system in men (Hoeft et al. 2008). Compared to the general population, a previous history of ICDs or substance abuse is less frequent in PD patients developing ICDs after the initiation of dopamine replacement therapy (Gallagher et al. 2007). More recently, the akinetic-rigid phenotype has been suggested to be more prone to impulsive responses and risk taking than tremor-dominant phenotype (Singh-Curry et al. 2010). An increased prevalence of executive dysfunctions in PD patients with ICD behaviors 
Table 1 Genes involved in impulse control disorders, substance addiction and associated traits in PD and non-PD populations

\begin{tabular}{|c|c|c|c|c|c|}
\hline $\begin{array}{l}\text { Transmitter } \\
\text { system }\end{array}$ & Protein & Gene/allele & Population & ICDs/addiction & References \\
\hline \multirow[t]{5}{*}{ Dopamine } & DAT & SLCA3 & Non-PD & $\begin{array}{l}\text { ICDs (BE, HS), substance abuse, } \\
\text { reward sensitivity and } \\
\text { impulsivity }\end{array}$ & $\begin{array}{l}\text { Muramatsu and Higuchi 1995; Shinohara } \\
\text { et al. 2004; Kreek et al. 2005; Guo et al. } \\
\text { 2007; Forbes } \\
\text { et al. 2009; Hahn et al. } 2010\end{array}$ \\
\hline & DRD1 & $800 \mathrm{~T} / \mathrm{C}$ & Non-PD & ICDs (PG), substance abuse & Comings et al. 1997; da Silva et al. 2007 \\
\hline & $\begin{array}{l}\text { DRD2/ } \\
\text { ANKK1 }\end{array}$ & TaqlA & Non-PD & $\begin{array}{l}\text { ICDs (PG, BE), alcohol and } \\
\text { nicotine abuse }\end{array}$ & $\begin{array}{l}\text { Blum et al. 1995; Comings et al. 1996; } \\
\text { Neville et al. 2004; Gelernter et al. 2006; } \\
\text { Yang et al. 2007; Haile et al. } 2007\end{array}$ \\
\hline & DRD3 & $\mathrm{p}-\mathrm{S} 9 \mathrm{G}$ & $\begin{array}{l}\text { Non-PD, } \\
\text { PD }\end{array}$ & $\begin{array}{l}\text { ICDs, alcohol abuse and risk } \\
\text { taking }\end{array}$ & Kreek et al. 2005; Lee et al. 2009 \\
\hline & DRD4 & $\begin{array}{l}\text { Exon III; } \\
\text { 7-repeat } \\
\text { allele }\end{array}$ & Non-PD & $\begin{array}{l}\text { ICDs (PG, BE), substance abuse } \\
\text { and novelty seeking }\end{array}$ & $\begin{array}{l}\text { Perez de Castro et al. 1997; Gelernter et al. } \\
\text { 1997; Comings et al. 1999; Levitan et al. } \\
\text { 2004; Rogers et al. 2004; Eisenegger } 2010\end{array}$ \\
\hline \multirow[t]{2}{*}{ Catecholaminergic } & COMT & Val158Met & Non-PD & $\begin{array}{l}\text { ICDs }(\mathrm{BE}) \text {, substance abuse and } \\
\text { reward sensitivity }\end{array}$ & $\begin{array}{l}\text { Kreek et al. 2005; Hersrud et al. 2009; } \\
\text { Lohoff et al. 2008; Dreher et al. } 2009\end{array}$ \\
\hline & MAD-A & $\begin{array}{l}\text { Promoter: } \\
\text { 3-repeat } \\
\text { allete }\end{array}$ & Non-PD & ICDs (PG) & Ibanez et al. 2000; Petez de Castro et al. 2002 \\
\hline \multirow[t]{2}{*}{ Serotonergic } & $\begin{array}{l}\text { Serotonin } \\
\text { transporter }\end{array}$ & SLC6A4 & Non-PD & $\begin{array}{l}\text { ICDs (PG, CS, TM), substance } \\
\text { abuse }\end{array}$ & $\begin{array}{l}\text { Perez de Castro et al. } 1999 \text { and 2002; Devor } \\
\text { et al. 1999; Hemmings et al. } 2006\end{array}$ \\
\hline & $\begin{array}{l}\text { Tryptophan } \\
\text { hydroxylase }\end{array}$ & TPH1 & Non-PD & ICDs (PG), substance abuse & $\begin{array}{l}\text { Comings et al. 2001; Kreek et al. 2005; } \\
\text { Nielsen et al. } 2008\end{array}$ \\
\hline Glutamatergic & $\begin{array}{l}\text { NMDA } \\
\text { receptor 2B }\end{array}$ & GRIN2B & $\begin{array}{l}\text { Non-PD, } \\
\text { PD }\end{array}$ & ICDs, alcohol abuse & Kim et al. 2006; Lee et al. 2009 \\
\hline Opioid & $\mu / \mathrm{K}$ receptors & $\begin{array}{l}\text { OPRM1; } \\
\text { OPRK1 }\end{array}$ & Non-PD & Substance abuse, impulsivity & Kreek et al. 2005; Olmstead et al. 2009 \\
\hline
\end{tabular}

ANKK1 ankyrin repeat and kinase domain containing-1 gene, $B E$ binge eating, $C S$ compulsive shopping, COMT catechol-O-methyl-transferase, $D A T$ dopamine transporter, $D R D$ dopamine receptor gene, $H S$ hypersexuality, ICDs impulse control disorders, MAO-A monoamine oxidase A, $N M D A$ N-methyl-D-aspartate, $P G$ pathological gambling, SERT serotonin transporter, $T M$ trichotillomania

is controversial, as found in the study of Santangelo et al. (Santangelo et al. 2009), while no differences in frontal lobe functions between gamblers versus non-gamblers have been reported in other studies (Siri et al. 2010; Voon et al. 2007). Further studies are needed to assess cognitive profiles of large samples of PD patients with and without ICDs, particularly focusing on frontal lobe functions while reliably eliminating potential biases such as age differences.

In the non-parkinsonian population, there seems to be a close association between individual vulnerability to risktaking behaviors and genetically determined variants in different neurotransmitter systems, mainly the dopaminergic mesocorticolimbic circuit (Brewer and Potenza 2008; Forbes et al. 2009; Haile et al. 2007). The mesolimbic dopaminergic transmission is centrally involved in the motivational salience of stimuli and appetitive or rewarddependent behaviors (Berridge and Robinson 2003). In particular, distinct differences in magnitude and pattern of dopamine release in the ventral striatum have been linked to disorders involving enhanced reward seeking, such as addiction and ICDs (Hyman et al. 2006).
In Table 1, we provide an overview of genetic findings in non-parkinsonian individuals with ICDs, focusing on dopamine transmission but not without taking a glance at other neurotransmitter systems.

\section{Neurobiological hypotheses in the non-parkinsonian population}

In the last few years, ICDs such as pathological gambling have been increasingly regarded as a 'behavioral addiction' (Goudriaan et al. 2004; Potenza 2008; Tamminga and Nestler 2006). Many of the diagnostic criteria for ICDs share features with those for substance use disorders, underscoring its classification as 'behavioral addiction' in the fifth edition of the Diagnostic and Statistical Manual of Mental Disorders (DSM, American Psychiatric Association, 1994). The main features of substance use disorders include: (a) enhanced salience attribution to drug-related stimuli in comparison to other natural rewards, (b) failure to inhibit the urge to obtain the drug, (c) withdrawal symptoms including cue-induced craving and (d) continued engagement in maladaptive risk- 
taking behaviors despite negative future consequences (Goldstein and Volkow 2002; Kalivas and Volkow 2005). Several of these common features are modulated by dopamine and are therefore of great interest, as they may constitute possible mediators of ICDs in subjects chronically treated with dopaminergic drugs and will thus be reviewed in the following paragraphs.

Although we focus on dopamine, other neurotransmitters (e.g., serotonin and opioids) may also be involved in the development of impulse control and addictive disorders. Serotoninergic neurons project form the raphe nucleus to mesocorticolimbic areas including prefrontal/orbitofrontal cortex, amygdala and hippocampus and are known to modulate delay discounting and reversal learning (Clarke et al. 2004; Rogers 2011). Moreover, forebrain serotonin levels were found to be negatively correlated with measures of impulsivity (Brewer and Potenza 2008) and risk-taking behavior (Potenza 2001; Moreno et al. 2010). The mu-opioid system is activated in response to gambling behavior (Shinohara et al. 2004) and is involved in the processing of hedonic responses and incentive motivation by modulating the nucleus accumbens and the ventral globus pallidum, either directly (Smith et al. 2009) or indirectly, via gamma-aminobutyric acid input to the mesolimbic dopamine pathway (Ikemoto et al. 1997; Grant et al. 2003; Olmstead et al. 2009).

DA-mediated mechanisms leading to (drug-related and behavioral) addiction

Exposure to rewards, including drugs of abuse and behaviors (such as gambling, sex or eating), induce phasic dopamine release from the ventral tegmental area into the nucleus accumbens, a process that is associated with reinforcement effects underlying stimulus-response conditioned learning and amplify salience attribution to the specific reward (Volkow et al. 2008). Repeated exposure to the reward-drug or behavior-may result in over-activation of the reward and motivational circuits (including the medial orbitofrontal cortex, OFC) while decreasing the top-down control of inhibitory cortical areas (including the ACC) (Potenza 2008). Pathologically increased saliency attribution to a particular reward produces an irresistible and increasingly compulsive drive toward that reward and away from other reinforcers, finally leading to withdrawal symptoms and craving, similar to substance use disorders (Hyman 2005; Robinson and Berridge 1993) and which has been hypothesized to be mediated by changes in dopamine and glutamate functioning (Kalivas and Volkow 2005).

Personality, behavior and cognition

The role of personality measures in the development of ICDs, such as sensation seeking and extraversion, is still controversial (Brand et al. 2005; Goudriaan et al. 2009; Jimenez-Murcia et al. 2010; Leiserson and Pihl 2007). Cognitive functions in non-parkinsonian subjects with PG demonstrated reduced decision-making abilities and executive dysfunction compared to controls (Alessi and Petry 2003; Brand et al. 2005; Forbush et al. 2008; Goudriaan et al. 2005; Kalechstein et al. 2007; Labudda et al. 2007; Lakey et al. 2006; Marazziti et al. 2008). In particular, nonparkinsonian gamblers show enhanced impulsivity together with impaired cognitive flexibility with higher rates of perseveration and impaired response inhibition. This is in consistence with studies in substance abuse (Forbush et al. 2008; Goudriaan et al. 2004; Kalechstein et al. 2007; Kertzman et al. 2008). Notably, decision-making impairment in pathological gamblers mainly includes reduced response shifting after losses (Goudriaan et al. 2006), supporting the hypothesis of impaired sensitivity to negative reinforcers and thus affecting the so-called 'win-staylose-shift' heuristic.

\section{Neuroimaging findings}

Studies using functional neuroimaging in healthy subjects demonstrated that rewarding events increase activity in the medial OFC, amygdala and ventral striatum (Hampton et al. 2007; Knutson and Cooper 2005; Yacubian et al. 2006), while increased brain activity in the ventrolateral prefrontal cortex (vlPFC), ACC and ventral striatum is generally associated with decision making under risk (Hewig et al. 2009; Hollander et al. 2005; Rao et al. 2008; Tom et al. 2007).

Resting state brain metabolism of pathological gamblers was found to be higher than matched controls in the medial OFC and other medial prefrontal cortical areas (Hollander et al. 2008). Similarly, in subjects with Internet game overuse, increased glucose metabolism in the medial OFC, the caudate and the insula was associated with greater impulsiveness compared to controls (Park et al. 2010). Reduced activation of the ventral striatum and the ventral prefrontal cortex during non-specific rewarding and punishing events has been shown in non-parkinsonian pathological gamblers, subjects with eating disorders and drug abusers compared to normal controls (de Ruiter et al. 2009; Potenza 2008; Reuter et al. 2005), suggesting a blunted response to rewards as well as to losses. On the other hand, also in pathological gamblers, lower vlPFC activity was found during monetary loss (de Ruiter et al. 2009), which is consistent with a diminished sensitivity to negative reinforcers (Goudriaan et al. 2005).

To say it in one grossly simplified sentence: neuroimaging evidence in the non-parkinsonian population points toward a reduced engagement of brain areas involved in the prevention of negative outcomes via inhibitory circuits 
(e.g., vlPFC) and an amplified engagement of areas mediating goal-directed behavior via motivational circuits (e.g., medial OFC).

\section{Possible pathophysiologic pathways fostering ICDs in PD}

Dopaminergic depletion in PD involves not only the nigrostriatal 'motor' loop, but also, though to a lesser degree, the mesocorticolimbic circuit, affecting the nucleus accumbens, OFC, ACC, amygdala and the hippocampus (Kish et al. 1988; Ouchi et al. 1999). All these regions are critically involved in the modulation of behavior in positive/negative reinforcement learning, motivation, inhibitory control and decision making (Frank et al. 2004; Schultz 2002; Tremblay and Schultz 1999). Thus, it is tempting to think that these brain regions must be-in one way or another-implicated in the development of ICDs. Moreover, the fact that in PD, mesocortical and mesolimbic circuitries are relatively intact, yet may undergo the same pharmacologic effect of dopaminergic treatment than the motor loop has led to the intuitive proposition of an 'overdosing' of the mesolimbic dopaminergic system (Cools and Robbins 2004). This mental concept is analogous to the 'overdose theory' of the frontal lobes, which we may ascribe to C. David Marsden's mastermind (Gotham et al. 1988). Note, however, that only a minority of PD patients on dopaminergic medication actually develop ICDs. Therefore, this concept-however intuitively convincing-_oes not give a sufficient answer to the most crucial questions associated with DAA-induced ICDs in PD: how do dopaminergic drugs generally alter limbic brain functions? What is different in the brain of susceptible PD patients? And what exactly happens in their brain that does not happen in the majority of PD patients? Recent imaging studies have begun to shed some light on those questions.

General drug-mediated changes in reward processing and reinforcement learning

Several lines of evidence point toward a reduced sensitivity of the reward system as a key feature in drug addiction and pathological gambling in the non-parkinsonian population (Goldstein et al. 2007; Potenza 2008; Reuter et al. 2005). In line with this notion, Riba et al. found that DAA leads to blunted neuronal responses to unexpected financial wins in the ventral striatum of healthy subjects (Riba et al. 2008). Extending this result to PD patients and comparing DAA and levodopa medication effects, van Eimeren et al. found that both medications reduced reward sensitivity in the ventral striatum, but only DAA greatly diminished reward sensitivity in the OFC (van Eimeren et al. 2009).
Moreover, there is ample evidence that DAAs disrupt appropriate feedback from negative outcomes in reinforcement learning. Behaviorally, PD patients are less able to learn from negative feedback when medicated with DAA (Bodi et al. 2009; Cools et al. 2006; Frank et al. 2004). Neurophysiologically, DAAs seem to prevent decreases in DA transmission that occur with negative feedback (van Eimeren et al. 2009). Indeed, abnormalities found in reward and punishment sensitivity could generally result in aberrant expectations of reward and loss and, consequently, to a pathological 'over-optimism', contributing to the continuation of behaviors such as pathological gambling. Yet, more studies are definitely needed to disentangle general (all patients) from specific (only vulnerable patients) DAA effects on reward and reinforcement learning.

Characteristic features of dopaminergic mesolimbic synapses

In a recent [11C]-raclopride PET study, (Steeves et al. 2009) compared levels of D2-receptor availability in PD patients with and without DAA-induced ICD behavior. Reduced availability of striatal D2-receptors was found to be a distinctive feature of the vulnerable patient group. This result is well in accordance with equivalent findings in drug addiction, in which decreased D2 receptor availability in combination with impaired OFC and ACC metabolism has been found (Volkow et al. 2001). A reduction in D2 receptor availability possibly constitutes a vulnerability that is genetically determined (see Table 1). In healthy volunteers, this genetically driven reduction in D2-receptors leads to impaired recruitment of the ACC and the right lateral OFC in negative feedback learning (Jocham et al. 2009). Note that reduced D2-receptor availability-as measured by [11C]-raclopride PET — can have three possible origins: reduced density of post-synaptic D2-receptors, increased levels of synaptic dopamine or both. In this respect, it is important to take into account another recent study measuring striatal dopamine transporter density with single photon emission tomography (Cilia et al. 2010). PD patients with DAA-induced ICD_as compared to patients without-demonstrated reduced levels of dopamine transporters specifically in the ventral striatum. Dopamine transporters are the single most important way to eliminate dopamine from the synaptic cleft. Therefore, it is tempting to infer increased levels of synaptic dopamine in vulnerable PD patients, which could also help explain the finding of reduced D2-receptor availability.

Characteristic patterns of neuronal activity

Similar to findings in the non-PD population (see "Neurobiological hypotheses in the non-parkinsonian 
population"), ICDs in PD patients seem to be associated with functional changes in circuitries that evaluate or mediate rewarding outcomes and/or evaluate risks during decision making. During rest and on regular dopaminergic medication, PD patients with active ICD behavior showed relatively increased blood flow in the OFC, the amygdala and globus pallidum indicative of a relative overactivity of those areas in an "idle" state (i.e., without engagement in a specific task) (Cilia et al. 2008). A recent fMRI study focused on the ventral striatum as a region of interest and found decreased resting blood flow together with reduced modulation of activity during risk taking in the ventral striatum of medicated PD patients with active ICDs (Rao et al. 2010). Another fMRI study investigated DAAinduced changes during a feedback learning task (Voon et al. 2010). In the ventral striatum, DAA medication specifically induced increased activation in relation to expected gains, while DAA medication diminished reactivity associated with expected losses in PD patients with active ICDs (Voon et al. 2010). Although these results may generally underscore the involvement of reward processing areas, the interpretation of activation data in this study is complicated by the fact that DAA medication also differentially modulated task performance in patients with and without ICD behavior. Investigating DAA-induced changes in regional brain activity during a card selection game with predetermined probabilistic outcomes, another recent imaging study found that only in vulnerable PD patients, DAA medication led to a deactivation of areas implicated in response inhibition and impulse control (vlPFC, ACC, amygdala, internal globus pallidus) (van Eimeren et al. 2010). It is interesting to note that most of the participants of this study were previously investigated with [11C]raclopride PET and showed reduced availability of striatal D2-receptors (Steeves et al. 2009). In good accordance with a differential modulation of corticostriatal inhibitory networks, a functional disconnection has been recently found between the ACC and the striatum in PD patients with ICDs (Cilia et al. 2011). This disconnection may be involved in the failure of loss-related behavioral shifts due to an inability to disengage from reward-seeking behaviors that previously gained abnormal salience via dopaminemediated positive reinforcements (Baler and Volkow 2006). Future neuroimaging studies in PD patients may help to confirm and extend these hypotheses by specifically focusing on differential and potential additive effects of various types of DAA and levodopa (Dewey 2010). Taking all available findings together, however, we may observe a striking analogy to the existing addiction literature that suggest a causal chain beginning with certain predisposing conditions of striatal dopamine synapses, an "unnatural" increase of dopamine stimulation and a characteristic pattern of resulting functional changes in remote networks of appetitive drive and impulse control (Potenza 2008; Volkow et al. 2001).

\section{The Yin and Yang of appetitive drive and inhibitory control: attempt of a unified hypothesis}

As mentioned before, DAA may increase appetitive drive (novelty seeking and impulsivity) while hampering negative feedback learning and behavioral inhibition. However, only a minority of PD patients actually develop ICD behaviors, suggesting an individual predisposition. One can only speculate on the underlying pharmacophysiologicpsychological interactions that drive behavioral change in susceptible patients. On the assumption of a relatively increased synaptic dopamine level in the striatum of vulnerable PD patients, we derive hypotheses based and an established model of the effects of tonic and phasic dopamine release on cortical connections with the direct and indirect pathways of the basal ganglia (Fig 2a). Decision making is believed to involve interactions of inhibitory and motivational inputs to the ventral striatum that are modified by convergent dopaminergic innervation from the ventral tegmental area (Goto et al. 2007). Phasic dopamine release, via D1 receptor activation, has been shown to facilitate inputs from motivational areas (e.g., medial OFC, frontopolar cortex) and thereby strengthens the influence of the direct or 'Go' pathway on executive areas (Goto and Grace 2005). Conversely, a transient reduction of tonic dopamine release, via D2-receptor inactivation, increases inputs from inhibitory areas (e.g., vlPFC and ACC) and thereby strengthens the influence of the indirect or 'NoGo' pathway on areas of executive control (Goto and Grace 2005).

Dopaminergic depletion in the ventral striatum of PD patients regularly decreases tonic D2-receptor stimulation. In susceptible patients on the other hand, a constitutionally increased tonic dopamine level would lead to a relatively normal level of tonic D2-receptor stimulation in the ventral striatum. According to the above-mentioned model, therapeutic use of DAA would further increase D2-receptor stimulation to the point of an "overdose" situation, leading to a hampered engagement of inhibitory cortical areas and increased influence of appetitive drive areas (Fig. 2b). This model would be in good accordance with findings in vulnerable PD patients, who showed reduced involvement of vlPFC and ACC and increased resting activity of the medial OFC in association with an increased tonic D2receptor stimulation (Cilia et al. 2008, 2010, 2011; Steeves et al. 2009; van Eimeren et al. 2010). While this hypothesis may be intuitively convincing, it will have to be tested in further studies involving genetic, behavioral and neuroimaging methods. 


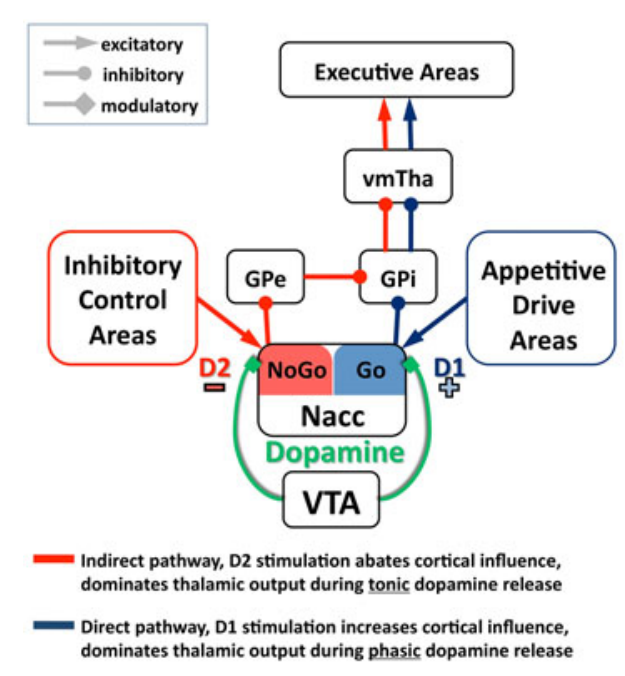

Fig. 2 The Yin-and-Yang model of appetitive drive and inhibitory control. Left The effects of tonic and phasic dopamine release on cortical connections with the direct and indirect pathways of the basal ganglia (here nucleus accumbens (Nacc) and ventral tegmental area (VTA), modified model after Goto and Grace 2005). Right In a majority of the patients with PD, dopaminergic depletion decreases tonic D2-receptor stimulation in the ventral striatum/Nacc. In

\section{Future directions in pharmacology, imaging and genomics}

The management options of ICDs in PD are not entirely satisfactory. While there are no evidence-based treatment strategies available, the most common form of therapeutic intervention in DA-induced ICDs in PD is the tapering and substitution of DAA (Galpern and Stacy 2007). It might be worth trying another type of DAA, if the clinical effect of DAA is otherwise deemed superior to alternatives. Moreover, the notion of the so-called DAA withdrawal syndrome (DAWS)—defined as psychological (e.g., anxiety, panic attacks, depression) or physical (e.g., diaphoresis, orthostatic hypotension) symptoms caused by the tapering of DAAs (Rabinak and Nirenberg 2010; Schlesinger et al. 2010)_underscores an urgent need for more therapeutic options for the clinician. Although case reports suggest possible roles for subthalamic stimulation (Bandini et al. 2007; Halbig et al. 2009) (but see Moro 2009), enteral carbidopa/levodopa infusions, amantadine, zonisamide, carbamazepine or clozapine (Bach et al. 2009; Bermejo et al. 2010; Gerschlager and Bloem 2009; Rotondo et al. 2010; Thomas et al. 2010), none of these potential add-on medications have been tested in prospective, randomized controlled trials. It is also worth mentioning that SSRI medications are commonly used in the treatment of nonparkinsonian ICDs and that opioid antagonists also seem to be effective (Leung and Cottler 2009), probably by increasing punishment sensitivity (Petrovic et al. 2008).

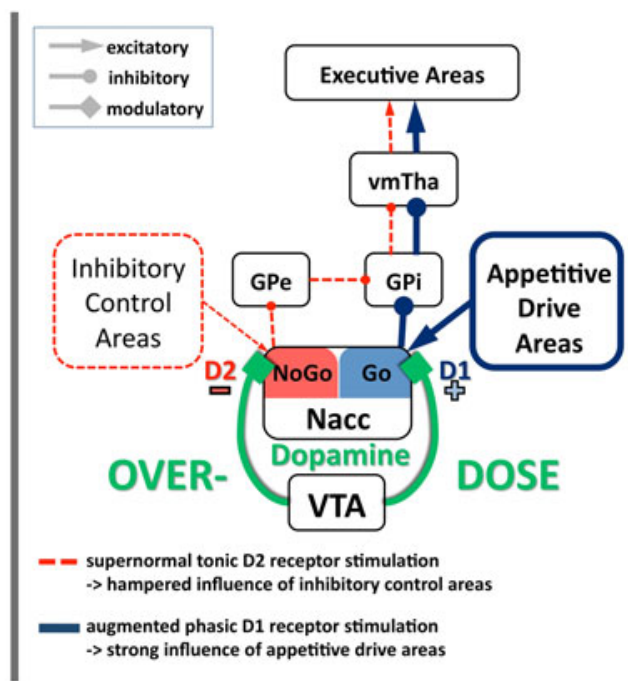

susceptible patients on the other hand, a constitutionally increased tonic dopamine level leads to relatively normal levels of tonic D2receptor stimulation in the ventral striatum/Nacc. Therapeutic use of DAA further increases D2-receptor stimulation to the point of an "overdose" situation, leading to a hampered engagement of inhibitory cortical areas and increased influence of appetitive drive areas

Future neuroimaging studies may contribute to direct attention to potential add-on medications by evaluating the influence of certain drugs (e.g., amantadine) on motivational and inhibitory circuitries.

Moreover, a steady flow of new neuroimaging studies will continue to increase our understanding of dopaminergic modulation of human behavior. It will be important to follow recent developments and to test hypotheses in clinically realistic circumstances (dopaminergic medication in parkinsonian populations). While most neuroimaging studies, for obvious reasons, will focus on the dopaminergic system, it will also be important to illuminate potentially crucial contributions of other neurotransmitter systems (as discussed above).

In the non-parkinsonian population, genetic factors of individual predisposition have been indentified (see Table 1). In the next few years, we need to systematically test genetic variances in large PD populations to potentially describe genetic makeups that may predict socially devastating side effects of anti-parkinsonian treatment. What we need is a better understanding of genetic determinants of pharmacologic effects on brain function. Functional imaging of pharmacogenetic interactions (imaging pharmacogenomics) will be an important tool to this end.

Acknowledgments The authors would like to express their deep gratitude toward their previous supervisors Antonio P. Strafella and Angelo Antonini for their generous advice and guidance in the recent years. The authors report no conflict of interests. 
Open Access This article is distributed under the terms of the Creative Commons Attribution Noncommercial License which permits any noncommercial use, distribution, and reproduction in any medium, provided the original author(s) and source are credited.

\section{References}

Alessi SM, Petry NM (2003) Pathological gambling severity is associated with impulsivity in a delay discounting procedure. Behav Processes 64:345-354.

Ardouin C, Voon V, Worbe Y, Abouazar N, Czernecki V, Hosseini H, Pelissolo A, Moro E, Lhommee E, Lang AE, Agid Y, Benabid AL, Pollak P, Mallet L, Krack P (2006) Pathological gambling in Parkinson's disease improves on chronic subthalamic nucleus stimulation. Mov Disord 21:1941-1946

Bach JP, Oertel WH, Dodel R, Jessen F (2009) Treatment of hypersexuality in Parkinson's disease with carbamazepine-a case report. Mov Disord 24:1241-1242

Baler RD, Volkow ND (2006) Drug addiction: the neurobiology of disrupted self-control. Trends Mol Med 12:559-566

Bandini F, Primavera A, Pizzorno M, Cocito L (2007) Using STN DBS and medication reduction as a strategy to treat pathological gambling in Parkinson's disease. Parkinsonism Relat Disord 13:369-371

Bermejo PE, Ruiz-Huete C, Anciones B (2010) Zonisamide in managing impulse control disorders in Parkinson's disease. J Neurol 257:1682-1685

Berridge KC, Robinson TE (2003) Parsing reward. Trends Neurosci 26:507-513

Bienfait KL, Menza M, Mark MH, Dobkin RD (2010) Impulsive smoking in a patient with Parkinson's disease treated with dopamine agonists. J Clin Neurosci 17:539-540

Blum K, Sheridan PJ, Wood RC, Braverman ER, Chen TJ, Comings DE (1995) Dopamine D2 receptor gene variants: association and linkage studies in impulsive-addictive-compulsive behaviour. Pharmacogenetics 5(3):121-141

Bodi N, Keri S, Nagy H, Moustafa A, Myers CE, Daw N, Dibo G, Takats A, Bereczki D, Gluck MA (2009) Reward-learning and the novelty-seeking personality: a between- and within-subjects study of the effects of dopamine agonists on young Parkinson's patients. Brain 132:2385-2395

Bonfanti AB, Gatto EM (2010) Kleptomania, an unusual impulsive control disorder in Parkinson's disease? Parkinsonism Relat Disord 16:358-359

Brand M, Kalbe E, Labudda K, Fujiwara E, Kessler J, Markowitsch HJ (2005) Decision-making impairments in patients with pathological gambling. Psychiatry Res 133:91-99

Brewer JA, Potenza MN (2008) The neurobiology and genetics of impulse control disorders: relationships to drug addictions. Biochem Pharmacol 75:63-75

Cilia R, Siri C, Marotta G, Isaias IU, De Gaspari D, Canesi M, Pezzoli G, Antonini A (2008) Functional abnormalities underlying pathological gambling in Parkinson disease. Arch Neurol 65:1604-1611

Cilia R, Ko JH, Cho SS, van Eimeren T, Marotta G, Pellecchia G, Pezzoli G, Antonini A, Strafella AP (2010) Reduced dopamine transporter density in the ventral striatum of patients with Parkinson's disease and pathological gambling. Neurobiol Dis 39:98-104

Cilia R, Cho SS, van Eimeren T, Marotta G, Siri C, Ko JH, Pellecchia G, Pezzoli G, Antonini A, Strafella AP (2011) Pathological gambling in patients with Parkinson's disease is associated with fronto-striatal disconnection: a path modeling analysis. Mov Disord 26:225-233

Clarke HF, Dalley JW, Crofts HS, Robbins TW, Roberts AC (2004) Cognitive inflexibility after prefrontal serotonin depletion. Science 304:878-880

Comings DE, Rosenthal RJ, Lesieur HR, Rugle LJ, Muhleman D, Chiu C et al (1996) A study of the dopamine D2 receptor gene in pathological gambling. Pharmacogenetics 6(3):223-234

Comings DE, Gade R, Wu S, Chiu C, Dietz G, Muhleman D et al (1997) Studies of the potential role of the dopamine D1 receptor gene in addictive behaviors. Mol Psychiatry 2(1):44-56

Comings DE, Gonzalez N, Wu S, Gade R, Muhleman D, Saucier G et al (1999) Studies of the $48 \mathrm{bp}$ repeat polymorphism of the DRD4 gene in impulsive, compulsive, addictive behaviors: Tourette syndrome, ADHD, pathological gambling, and substance abuse. Am J Med Genet 88(4):358-368

Comings DE, Gade-Andavolu R, Gonzalez N, Wu S, Muhleman D, Chen $C$ et al (2001) The additive effect of neurotransmitter genes in pathological gambling. Clin Genet 60(2):107-116

Cools R, Robbins TW (2004) Chemistry of the adaptive mind. Philos Transact A Math Phys Eng Sci 362:2871-2888

Cools R, Altamirano L, D'Esposito M (2006) Reversal learning in Parkinson's disease depends on medication status and outcome valence. Neuropsychologia 44:1663-1673

Cornelius JR, Tippmann-Peikert M, Slocumb NL, Frerichs CF, Silber MH (2010) Impulse control disorders with the use of dopaminergic agents in restless legs syndrome: a case-control study. Sleep 33:81-87

Crockford D, Quickfall J, Currie S, Furtado S, Suchowersky O, ElGuebaly N (2008) Prevalence of problem and pathological gambling in Parkinson's disease. J Gambl Stud 24:411-422

da Silva Lobo DS, Vallada HP, Knight J, Martins SS, Tavares H, Gentil V, Kennedy JL (2007) Dopamine genes and pathological gambling in discordant sib-pairs. J Gambl Stud 23(4):421-433

Dalley JW, Everitt BJ, Robbins TW (2011) Impulsivity, compulsivity, and top-down cognitive control. Neuron 69:680-694

de Ruiter MB, Veltman DJ, Goudriaan AE, Oosterlaan J, Sjoerds Z, van den Brink W (2009) Response perseveration and ventral prefrontal sensitivity to reward and punishment in male problem gamblers and smokers. Neuropsychopharmacology 34:1027-1038

Devor EJ, Magee HJ, Dill-Devor RM, Gabel J, Black DW (1999) Serotonin transporter gene (5-HTT) polymorphisms and compulsive buying. Am J Med Genet 88(2):123-125

Dewey RB Jr (2010) Pathological gambling in PD: did the devil make me do it? Neurology 75:1668-1669

Dreher JC, Kohn P, Kolachana B, Weinberger DR, Berman KF (2009) Variation in dopamine genes influences responsivity of the human reward system. Proc Natl Acad Sci USA 13 106(2):617-622 Epub 2008 Dec 22

Driver-Dunckley E, Samanta J, Stacy M (2003) Pathological gambling associated with dopamine agonist therapy in Parkinson's disease. Neurology 61:422-423

Eisenegger C, Knoch D, Ebstein RP, Gianotti LR, Sándor PS, Fehr E (2010) Dopamine receptor D4 polymorphism predicts the effect of L-DOPA on gambling behavior. Biol Psychiatry 67(8):702-706

Evans AH, Katzenschlager R, Paviour D, O'Sullivan JD, Appel S, Lawrence AD, Lees AJ (2004) Punding in Parkinson's disease: its relation to the dopamine dysregulation syndrome. Mov Disord 19:397-405

Evans AH, Strafella AP, Weintraub D, Stacy M (2009) Impulsive and compulsive behaviors in Parkinson's disease. Mov Disord 24:1561-1570

Forbes EE, Brown SM, Kimak M, Ferrell RE, Manuck SB, Hariri AR (2009) Genetic variation in components of dopamine neurotransmission impacts ventral striatal reactivity associated with impulsivity. Mol Psychiatry 14:60-70 
Forbush KT, Shaw M, Graeber MA, Hovick L, Meyer VJ, Moser DJ, Bayless J, Watson D, Black DW (2008) Neuropsychological characteristics and personality traits in pathological gambling. CNS Spectr 13:306-315

Frank MJ, Seeberger LC, O'Reilly RC (2004) By carrot or by stick: cognitive reinforcement learning in parkinsonism. Science 306:1940-1943

Frank MJ, Samanta J, Moustafa AA, Sherman SJ (2007) Hold your horses: impulsivity, deep brain stimulation, and medication in parkinsonism. Science 318:1309-1312

Gallagher DA, O'Sullivan SS, Evans AH, Lees AJ, Schrag A (2007) Pathological gambling in Parkinson's disease: risk factors and differences from dopamine dysregulation. An analysis of published case series. Mov Disord 22:1757-1763

Galpern WR, Stacy M (2007) Management of impulse control disorders in Parkinson's disease. Curr Treat Options Neurol 9:189-197

Gelernter J, Kranzler H, Coccaro E, Siever L, New A, Mulgrew CL (1997) D4 dopamine-receptor (DRD4) alleles and novelty seeking in substance-dependent, personality-disorder, and control subjects. Am J Hum Genet 61(5):1144-1152

Gelernter J, Yu Y, Weiss R, Brady K, Panhuysen C, Yang BZ, Kranzler HR, Farrer L (2006) Haplotype spanning TTC12 and ANKK1, flanked by the DRD2 and NCAM1 loci, is strongly associated to nicotine dependence in two distinct American populations. Hum Mol Genet 15(24):3498-3507

Gerschlager W, Bloem BR (2009) Managing pathological gambling in Parkinson's disease with enteral levodopa/carbidopa infusions. Mov Disord 24:1858-1860

Goldstein RZ, Volkow ND (2002) Drug addiction and its underlying neurobiological basis: neuroimaging evidence for the involvement of the frontal cortex. Am J Psychiatry 159:1642-1652

Goldstein RZ, Tomasi D, Alia-Klein N, Cottone LA, Zhang L, Telang F, Volkow ND (2007) Subjective sensitivity to monetary gradients is associated with frontolimbic activation to reward in cocaine abusers. Drug Alcohol Depend 87:233-240

Gotham AM, Brown RG, Marsden CD (1988) 'Frontal' cognitive function in patients with Parkinson's disease 'on' and 'off' levodopa. Brain 111(Pt 2):299-321

Goto Y, Grace AA (2005) Dopaminergic modulation of limbic and cortical drive of nucleus accumbens in goal-directed behavior. Nat Neurosci 8:805-812

Goto Y, Otani S, Grace AA (2007) The Yin and Yang of dopamine release: a new perspective. Neuropharmacology 53:583-587

Goudriaan AE, Oosterlaan J, de Beurs E, Van den Brink W (2004) Pathological gambling: a comprehensive review of biobehavioral findings. Neurosci Biobehav Rev 28:123-141

Goudriaan AE, Oosterlaan J, de Beurs E, van den Brink W (2005) Decision making in pathological gambling: a comparison between pathological gamblers, alcohol dependents, persons with Tourette syndrome, and normal controls. Brain Res Cogn Brain Res 23:137-151

Goudriaan AE, Oosterlaan J, de Beurs E, van den Brink W (2006) Neurocognitive functions in pathological gambling: a comparison with alcohol dependence, Tourette syndrome and normal controls. Addiction 101:534-547

Goudriaan AE, Slutske WS, Krull JL, Sher KJ (2009) Longitudinal patterns of gambling activities and associated risk factors in college students. Addiction 104:1219-1232

Grant JE, Kim SW, Potenza MN (2003) Advances in the pharmacological treatment of pathological gambling. J Gambl Stud 19:85-109

Grosset KA, Grosset DG, Macphee G, Pal G, Stewart D, Watt A, Davie J (2007) Dopamine agonists and pathological gambling. Parkinsonism Relat Disord 13:259 (author reply 260)
Guo G, Tong Y, Xie CW, Lange LA (2007) Dopamine transporter, gender, and number of sexual partners among young adults. Eur J Hum Genet 15(3):279-287

Hahn T, Heinzel S, Dresler T, Plichta MM, Renner TJ, Markulin F et al (2010) Association between reward-related activation in the ventral striatum and trait reward sensitivity is moderated by dopamine transporter genotype. Hum Brain Mapp. doi:10.1002/ hbm.21127. [Epub ahead of print]

Haile CN, Kosten TR, Kosten TA (2007) Genetics of dopamine and its contribution to cocaine addiction. Behav Genet 37:119-145

Halbig TD, Tse W, Frisina PG, Baker BR, Hollander E, Shapiro H, Tagliati M, Koller WC, Olanow CW (2009) Subthalamic deep brain stimulation and impulse control in Parkinson's disease. Eur J Neurol 16:493-497

Hampton AN, Adolphs R, Tyszka MJ, O’Doherty JP (2007) Contributions of the amygdala to reward expectancy and choice signals in human prefrontal cortex. Neuron 55:545-555

Hemmings SM, Kinnear CJ, Lochner C, Seedat S, Corfield VA, Moolman-Smook JC, Stein DJ (2006) Genetic correlates in trichotillomania-a case-control association study in the South African Caucasian population. Isr J Psychiatry Relat Sci 43(2):93-101

Hersrud SL, Stoltenberg SF (2009) Epistatic interaction between COMT and DAT1 genes on eating behavior: a pilot study. Eat Behav 10(2):131-133

Hewig J, Straube T, Trippe RH, Kretschmer N, Hecht H, Coles MG, Miltner WH (2009) Decision-making under risk: an fMRI study. J Cogn Neurosci 21:1642-1652

Hoeft F, Watson CL, Kesler SR, Bettinger KE, Reiss AL (2008) Gender differences in the mesocorticolimbic system during computer game-play. J Psychiatr Res 42:253-258

Hollander E, Pallanti S, Baldini Rossi N, Sood E, Baker BR, Buchsbaum MS (2005) Imaging monetary reward in pathological gamblers. World J Biol Psychiatry 6:113-120

Hollander E, Buchsbaum, Haznedar MM, Berenguer J, Berlin HA, Chaplin W, Goodman CR, LiCalzi EM, Newmark R, Pallanti S (2008) FDG-PET study in pathological gamblers. 1. Lithium increases orbitofrontal, dorsolateral and cingulate metabolism. Neuropsychobiology 58:37-47

Holman AJ (2009) Impulse control disorder behaviors associated with pramipexole used to treat fibromyalgia. J Gambl Stud $25: 425-431$

Hyman SE (2005) Addiction: a disease of learning and memory. Am J Psychiatry 162:1414-1422

Hyman SE, Malenka RC, Nestler EJ (2006) Neural mechanisms of addiction: the role of reward-related learning and memory. Annu Rev Neurosci 29:565-598

Ibañez A, Perez de Castro I, Fernandez-Piqueras J, Blanco C, Saiz-Ruiz J (2000) Pathological gambling and DNA polymorphic markers at MAO-A and MAO-B genes. Mol Psychiatry 5(1):105-109

Ikemoto S, Kohl RR, McBride WJ (1997) GABA(A) receptor blockade in the anterior ventral tegmental area increases extracellular levels of dopamine in the nucleus accumbens of rats. J Neurochem 69(1):137-143

Jimenez-Murcia S, Alvarez-Moya EM, Stinchfield R, FernandezAranda F, Granero R, Aymami N, Gomez-Pena M, Jaurrieta N, Bove F, Menchon JM (2010) Age of onset in pathological gambling: clinical, therapeutic and personality correlates. J Gambl Stud 26:235-248

Jocham G, Klein TA, Neumann J, von Cramon DY, Reuter M, Ullsperger M (2009) Dopamine DRD2 polymorphism alters reversal learning and associated neural activity. J Neurosci 29:3695-3704

Kalechstein AD, Fong T, Rosenthal RJ, Davis A, Vanyo H, Newton $\mathrm{TF}$ (2007) Pathological gamblers demonstrate frontal lobe 
impairment consistent with that of methamphetamine-dependent individuals. J Neuropsychiatry Clin Neurosci 19:298-303

Kalivas PW, Volkow ND (2005) The neural basis of addiction: a pathology of motivation and choice. Am J Psychiatry 162:1403-1413

Kertzman S, Lowengrub K, Aizer A, Vainder M, Kotler M, Dannon PN (2008) Go-no-go performance in pathological gamblers. Psychiatry Res 161:1-10

Kim JH, Park M, Yang SY, Jeong BS, Yoo HJ, Kim JW et al (2006) Association study of polymorphisms in N-methyl-D-aspartate receptor 2B subunits (GRIN2B) gene with Korean alcoholism. Neurosci Res 56(2):220-223

Kish SJ, Shannak K, Hornykiewicz O (1988) Uneven pattern of dopamine loss in the striatum of patients with idiopathic Parkinson's disease. Pathophysiologic and clinical implications. N Engl J Med 318:876-880

Knutson B, Cooper JC (2005) Functional magnetic resonance imaging of reward prediction. Curr Opin Neurol 18:411-417

Kreek MJ, Nielsen DA, Butelman ER, LaForge KS (2005) Genetic influences on impulsivity, risk taking, stress responsivity and vulnerability to drug abuse and addiction. Nat Neurosci 8(11):1450-1457

Labudda K, Wolf OT, Markowitsch HJ, Brand M (2007) Decisionmaking and neuroendocrine responses in pathological gamblers. Psychiatry Res 153:233-243

Lakey CE, Goodie AS, Campbell WK (2006) Frequent card playing and pathological gambling: the utility of the Georgia gambling task and iowa gambling task for predicting pathology. J Gambl Stud [Epub ahead of print]

Lee JY, Lee EK, Park SS, Lim JY, Kim HJ, Kim JS, Jeon BS (2009) Association of DRD3 and GRIN2B with impulse control and related behaviors in Parkinson's disease. Mov Disord 15 24(12):1803-1810

Lee JY, Kim JM, Kim JW, Cho J, Lee WY, Kim HJ, Jeon BS (2010) Association between the dose of dopaminergic medication and the behavioral disturbances in Parkinson disease. Parkinsonism Relat Disord 16:202-207

Leiserson V, Pihl RO (2007) Reward-sensitivity, inhibition of rewardseeking, and dorsolateral prefrontal working memory function in problem gamblers not in treatment. J Gambl Stud 23:435-455

Leung KS, Cottler LB (2009) Treatment of pathological gambling. Curr Opin Psychiatry 22:69-74

Levitan RD, Masellis M, Basile VS, Lam RW, Kaplan AS, Davis C et al (2004) The dopamine-4 receptor gene associated with binge eating and weight gain in women with seasonal affective disorder: an evolutionary perspective. Biol Psychiatry 56(9):665-669

Lim SY, O'Sullivan SS, Kotschet K, Gallagher DA, Lacey C, Lawrence AD, Lees AJ, O'Sullivan DJ, Peppard RF, Rodrigues JP, Schrag A, Silberstein P, Tisch S, Evans AH (2009) Dopamine dysregulation syndrome, impulse control disorders and punding after deep brain stimulation surgery for Parkinson's disease. J Clin Neurosci 16:1148-1152

Lohoff FW, Weller AE, Bloch PJ, Nall AH, Ferraro TN, Kampman $\mathrm{KM}$ et al (2008) Association between the catechol-O-methyltransferase Val158Met polymorphism and cocaine dependence. Neuropsychopharmacology 33(13):3078-3084

Marazziti D, Catena Dell'osso M, Conversano C, Consoli G, Vivarelli L, Mungai F, Di Nasso E, Golia F (2008) Executive function abnormalities in pathological gamblers. Clin Pract Epidemiol Ment Health 4:7

Moreno M, Cardona D, Gomez MJ, Sanchez-Santed F, Tobeña A, Fernandez-Teruel A, Campa L, Suñol C, Escarabajal MD, Torres C, Flores P (2010) Impulsivity characterization in the Roman highand low-avoidance rat strains: behavioral and neurochemical differences. Neuropsychopharmacology 35:1198-1208
Moro E (2009) Impulse control disorders and subthalamic nucleus stimulation in Parkinson's disease: are we jumping the gun? Eur J Neurol 16:440-441

Munro CA, McCaul ME, Wong DF, Oswald LM, Zhou Y, Brasic J, Kuwabara H, Kumar A, Alexander M, Ye W, Wand GS (2006) Sex differences in striatal dopamine release in healthy adults. Biol Psychiatry 59:966-974

Muramatsu T, Higuchi S (1995) Dopamine transporter gene polymorphism and alcoholism. Biochem Biophys Res Commun 211(1):28-32

Neville MJ, Johnstone EC, Walton RT (2004) Identification and characterization of ANKK1: a novel kinase gene closely linked to DRD2 on chromosome band 11q23.1. Hum Mutat 23(6):540-545

Nielsen DA, Barral S, Proudnikov D, Kellogg S, Ho A, Ott J, Kreek MJ (2008) TPH2 and TPH1: association of variants and interactions with heroin addiction. Behav Genet 38(2):133-150

O'Sullivan SS, Evans AH, Lees AJ (2009) Dopamine dysregulation syndrome: an overview of its epidemiology, mechanisms and management. CNS Drugs 23:157-170

Odiyoor M, Kobylecki C, Hackett RJ, Silverdale MA, Kellett MW (2009) Pramipexole and gender identity disorder: expanding the phenotype of hypersexuality in Parkinson's disease. Mov Disord 24:2434-2435

Olmstead MC, Ouagazzal AM, Kieffer BL (2009) Mu and delta opioid receptors oppositely regulate motor impulsivity in the signaled nose poke task. PLoS One 4:e4410

Ouchi Y, Yoshikawa E, Okada H, Futatsubashi M, Sekine Y, Iyo M, Sakamoto M (1999) Alterations in binding site density of dopamine transporter in the striatum, orbitofrontal cortex, and amygdala in early Parkinson's disease: compartment analysis for beta-CFT binding with positron emission tomography. Ann Neurol 45:601-610

Park HS, Kim SH, Bang SA, Yoon EJ, Cho SS, Kim SE (2010) Altered regional cerebral glucose metabolism in internet game overusers: a 18F-fluorodeoxyglucose positron emission tomography study. CNS Spectr 15:159-166

Petrovic P, Pleger B, Seymour B, Kloppel S, De Martino B, Critchley H, Dolan RJ (2008) Blocking central opiate function modulates hedonic impact and anterior cingulate response to rewards and losses. J Neurosci 28:10509-10516

Pérez de Castro I, Ibáñez A, Torres P, Sáiz-Ruiz J, FernándezPiqueras J (1997) Genetic association study between pathological gambling and a functional DNA polymorphism at the D4 receptor gene. Pharmacogenetics 7(5):345-348

Pérez de Castro I, Ibáñez A, Saiz-Ruiz J, Fernández-Piqueras J (1999) Genetic contribution to pathological gambling: possible association between a functional DNA polymorphism at the serotonin transporter gene (5-HTT) and affected men. Pharmacogenetics 9(3):397-400

Pérez de Castro I, Ibáñez A, Saiz-Ruiz J, Fernández-Piqueras J (2002) Concurrent positive association between pathological gambling and functional DNA polymorphisms at the MAO-A and the 5-HT transporter genes. Mol Psychiatry 7(9):927-928

Pinggera GM, Pichler R, Rehder P, Kerschbaumer A, Buttazzoni A, Zangerl F, Mitterberger M (2009) Penile strangulation in a patient with Parkinson's disease: a case report. Cases J 2:9379

Potenza MN (2001) The neurobiology of pathological gambling. Semin Clin Neuropsychiatry 6:217-226

Potenza MN (2008) Review. The neurobiology of pathological gambling and drug addiction: an overview and new findings. Philos Trans R Soc Lond B Biol Sci 363:3181-3189

Rabinak CA, Nirenberg MJ (2010) Dopamine agonist withdrawal syndrome in Parkinson disease. Arch Neurol 67:58-63

Rao H, Korczykowski M, Pluta J, Hoang A, Detre JA (2008) Neural correlates of voluntary and involuntary risk taking in the human 
brain: an fMRI Study of the Balloon Analog Risk Task (BART). Neuroimage 42:902-910

Rao H, Mamikonyan E, Detre JA, Siderowf AD, Stern MB, Potenza MN, Weintraub D (2010) Decreased ventral striatal activity with impulse control disorders in Parkinson's disease. Mov Disord 25:1660-1669

Reuter J, Raedler T, Rose M, Hand I, Glascher J, Buchel C (2005) Pathological gambling is linked to reduced activation of the mesolimbic reward system. Nat Neurosci 8:147-148

Riba J, Kramer UM, Heldmann M, Richter S, Munte TF (2008) Dopamine agonist increases risk taking but blunts reward-related brain activity. PLoS ONE 3:e2479

Robinson TE, Berridge KC (1993) The neural basis of drug craving: an incentive-sensitization theory of addiction. Brain Res Brain Res Rev 18:247-291

Rogers G, Joyce P, Mulder R, Sellman D, Miller A, Allington M et al (2004) Association of a duplicated repeat polymorphism in the 5 '-untranslated region of the DRD4 gene with novelty seeking. Am J Med Genet B Neuropsychiatr Genet 126B(1):95-98

Rogers RD (2011) The roles of dopamine and serotonin in decision making: evidence from pharmacological experiments in humans. Neuropsychopharmacology 36:114-132

Rotondo A, Bosco D, Plastino M, Consoli A, Bosco F (2010) Clozapine for medication-related pathological gambling in Parkinson disease. Mov Disord 25:1994-1995

Santangelo G, Vitale C, Trojano L, Verde F, Grossi D, Barone P (2009) Cognitive dysfunctions and pathological gambling in patients with Parkinson's disease. Mov Disord 24:899-905

Schlesinger I, Erikh I, Zaaroor M (2010) Dopamine agonist withdrawal syndrome: the apomorphine solution. Arch Neurol 67:1155 (author reply 1156)

Schultz W (2002) Getting formal with dopamine and reward. Neuron 36:241-263

Seedat S, Kesler S, Niehaus DJ, Stein DJ (2000) Pathological gambling behaviour: emergence secondary to treatment of Parkinson's disease with dopaminergic agents. Depress Anxiety 11:185-186

Shinohara M, Mizushima H, Hirano M, Shioe K, Nakazawa M, Hiejima $\mathrm{Y}$ et al (2004) Eating disorders with binge-eating behaviour are associated with the s allele of the $3^{\prime}$-UTR VNTR polymorphism of the dopamine transporter gene. J Psychiatry Neurosci 29(2):134-137

Singh-Curry V, Bunzeck N, O'Sullivan S, Molloy M, Perry R, Bain P, Lees A, Duzel E, Husain M (2010) PATH50 Novelty-seeking and risk-taking behaviour in subtypes of Parkinson's disease. J Neurol Neurosurg Psychiatry 81:e21

Siri C, Cilia R, De Gaspari D, Canesi M, Meucci N, Zecchinelli AL, Pezzoli G, Antonini A (2010) Cognitive status of patients with Parkinson's disease and pathological gambling. J Neurol 257:247-252

Smith KS, Tindell AJ, Aldridge JW, Berridge KC (2009) Ventral pallidum roles in reward and motivation. Behav Brain Res 196:155-167

Steeves TD, Miyasaki J, Zurowski M, Lang AE, Pellecchia G, van Eimeren T, Rusjan P, Houle S, Strafella AP (2009) Increased striatal dopamine release in Parkinsonian patients with pathological gambling: a [11C] raclopride PET study. Brain 132:1376-1385

Tamminga CA, Nestler EJ (2006) Pathological gambling: focusing on the addiction, not the activity. Am J Psychiatry 163:180-181

Thomas A, Bonanni L, Gambi F, Di Iorio A, Onofrj M (2010) Pathological gambling in Parkinson disease is reduced by amantadine. Ann Neurol 68:400-404

Tom SM, Fox CR, Trepel C, Poldrack RA (2007) The neural basis of loss aversion in decision-making under risk. Science 315:515-518

Tremblay L, Schultz W (1999) Relative reward preference in primate orbitofrontal cortex. Nature 398:704-708

van Eimeren T, Ballanger B, Pellecchia G, Miyasaki JM, Lang AE, Strafella AP (2009) Dopamine agonists diminish value sensitivity of the orbitofrontal cortex: a trigger for pathological gambling in Parkinson's disease? Neuropsychopharmacology 34:2758-2766

van Eimeren T, Pellecchia G, Cilia R, Ballanger B, Steeves TD, Houle S, Miyasaki JM, Zurowski M, Lang AE, Strafella AP (2010) Drug-induced deactivation of inhibitory networks predicts pathological gambling in PD. Neurology 75:1711-1716

Volkmann J, Daniels C, Witt K (2010) Neuropsychiatric effects of subthalamic neurostimulation in Parkinson disease. Nat Rev Neurol 6:487-498

Volkow ND, Chang L, Wang GJ, Fowler JS, Ding YS, Sedler M, Logan J, Franceschi D, Gatley J, Hitzemann R, Gifford A, Wong C, Pappas N (2001) Low level of brain dopamine D2 receptors in methamphetamine abusers: association with metabolism in the orbitofrontal cortex. Am J Psychiatry 158:2015-2021

Volkow ND, Wang GJ, Fowler JS, Telang F (2008) Overlapping neuronal circuits in addiction and obesity: evidence of systems pathology. Philos Trans R Soc Lond B Biol Sci 363:3191-3200

Voon V, Thomsen T, Miyasaki JM, de Souza M, Shafro A, Fox SH, Duff-Canning S, Lang AE, Zurowski M (2007) Factors associated with dopaminergic drug-related pathological gambling in Parkinson disease. Arch Neurol 64:212-216

Voon V, Pessiglione M, Brezing C, Gallea C, Fernandez HH, Dolan RJ, Hallett M (2010) Mechanisms underlying dopamine-mediated reward bias in compulsive behaviors. Neuron 65:135-142

Weintraub D, Koester J, Potenza MN, Siderowf AD, Stacy M, Voon V, Whetteckey J, Wunderlich GR, Lang AE (2010) Impulse control disorders in Parkinson disease: a cross-sectional study of 3,090 patients. Arch Neurol 67:589-595

Witjas T, Baunez C, Henry JM, Delfini M, Regis J, Cherif AA, Peragut JC, Azulay JP (2005) Addiction in Parkinson's disease: impact of subthalamic nucleus deep brain stimulation. Mov Disord 20:1052-1055

Yacubian J, Glascher J, Schroeder K, Sommer T, Braus DF, Buchel C (2006) Dissociable systems for gain- and loss-related value predictions and errors of prediction in the human brain. J Neurosci 26:9530-9537

Yang BZ, Kranzler HR, Zhao H, Gruen JR, Luo X, Gelernter J (2007) Association of haplotypic variants in DRD2, ANKK1, TTC12 and NCAM1 to alcohol dependence in independent case control and family samples. Hum Mol Genet 16(23):2844-2853 